\title{
Study of Hawthorne's Gothic Art Novel
}

\author{
Ke Zhang \\ International College of Huanghuai University, Zhumadian, 463000, China
}

\begin{abstract}
Keywords: Hawthorne, Gothic art, The novel, Gothic romance, Terror, Darkness, Inheritance, surpass
\end{abstract}

\begin{abstract}
Nathaniel Hawthorne is outstanding America in the 19th century romanticism writer; he inherited the essence of early British gothic fiction, created with the flavor of "gothic romance", a strong impact to the European Renaissance. In his works, we can not only see the darkness, also can see the light, so that he made in the English and American literature gothic romance darkness into light gray, can let people see hope, still can obtain spiritual freedom and identification of self-worth. This paper hope through Hawthorne's works to speculation gothic art characteristics under his brush strokes, and interpreted the early British gothic literature "American inheritance and beyond".
\end{abstract}

\section{Introduction}

The castle in the early British gothic literature, the chamber of secrets, ghosts, murder and other elements in Hawthorne's works are embodied. But in his charismatic of symbolism in literary expression, gothic style seems to be a wonderful appearance of modernity and imagination, both plot content, the scene atmosphere and artistic technique of expression, has a light gray "gothic romance" Hawthorne's brand mark, in love with his old British gothic novel readers feel refreshing.

\section{The characters in the works of Hawthorne}

Hawthorne in the so-called "American gothic" works, different from the traditional first is to pay attention to the depict of the character temperament, it get rid of the traditional gothic novel in the story to win. In Hawthorne's work, the characters are important symbols in the evolution of the plot, the reader can see Hawthorne works in the nature of human nature is the most true, although it does not have a traditional gothic novels that the characterization of magic and legends, but it would be a perfect combination of gothic art to their work, the overall characterization is plain, but which is able to reduce the distance with readers heart.

As a good use of symbolism romantic writer, Hawthorne is better to discuss the charm of human nature, beautiful, ugly and desires. In his view, the gothic art can inherit part is that is full of weird and complicated characters of "dark romanticism" style, but full of romanticism in his literary ideas, he thought with the ordinary people of special events can capture more readers, more can reflect the characters in the works, the power of emotional impact brings to the readers. So to savor Hawthorne's works, he in characters showed delicate side, and its character set is open, it is the traditional gothic art in the mystery and implicit elements of inheritance. Below it will be sent to you by Hawthorne's detailed analysis the characters of his works.

\section{The image portray of character}

Hawthorne is an American romantic literature ideological trend of the Portland trail blazers, he will be the American romanticism and English traditional gothic literature, formed the new literature with his style. In Hawthorne's works, although the readers can also see the evil demon, Christians and tender woman, but richer social connotation of Hawthorne's characters, this also reflected the Hawthorne in the first half of the 19th century strong transcendentalist characteristics.

Hawthorne's biggest breakthrough of traditional gothic literature is broken and the shaping of image features of black and white, he advocated is three-dimensional and full of "round character", this is more conducive to him from the view of the multiple of literature through the confrontation between good and evil characters to deeply explore the hidden moral, also good is evil human nature. So Hawthorne's characters are often in a mixed state of conflict between good and evil, in addition to 
skimming polarization between good and evil to depict the fuzziness of human nature, let the reader to the human nature to see more clearly.

The demon image features' describe

Demon image is the most common in the gothic novel and unique literary image, its aesthetic value conforms to the mysterious, strange and terror of gothic literature is a typical style of black. In Hawthorne's works, the devil type character also abound, are human and nonhuman he could be divided into two categories: the devil one kind is cruel wicked image, they by hook or by crook, bloodless, this style inherited the essence of traditional gothic literature; There is a devil is human image, such as witches, ghosts, ghosts, and so on surreal fantasy image. They are not human, but it can reflect the most intense collision between good and evil in human nature, future generations will Murtha this demon images for the allegorical narrative mode. Through these images, Hawthorne had to dig deep in some unknown secretive dark side of human nature. In the scarlet letter, Chillingworth is representative of the evil side; he is filled with the desire of revenge and rage for others. Hawthorne believes that Chillingworth "evil" and revenge heart from his goodness and character development, to him it was his goodness that let the hurt by adultery, and made him step by step to fall, from a kind person evolved into an extreme distortion of the avengers. When Chillingworth before he died, he will also be a sizable inheritance for Hester's daughter, and it reveals the kind he hasn't disappeared. The role of good, evil, good human nature changes, not only push forward the work of the whole plot evolution, also expressed the author "avoid evil from good" personality ideal, namely from the bright side of good and evil character noble the appreciate ${ }^{[1]}$.

Female image features' describe

Early gothic literature, female image is to reflect the brutality of the devil, so women in gothic literature is synonymous with "weak". Women in the works of Hawthorne, however, away from the traditional inherent vulnerability in gothic literature image, they are brave and has independent initiative of choice to the love. As in the scarlet letter, the heroine is not the traditional lady, she dare to love daring to hate, even under the teaching rights also dare to make public the human nature. Hester to society, to the family's rebellion is also reflected by this doctrine are not legally binding and real about the inner moral power.

In Hawthorne's view, human nature is evil, so he will work in the male authority compared to a source from the human soul of the abstract "evil". Create the ideology is to highlight his new female image on men's authority and the status of male cure to challenge. But Hawthorne also knows that in the patriarchal society background, even radical feminism cannot improve their existing status. So in the "happy valley legend", he will be in deep love mire Zeno Biya everywhere portrayed as a vent inner anguish dissatisfied housewife, she is arrogant, biased, cynical, ill-fated. Hawthorne expressed in this work of women's past the angel female images depicting the norm, want to use another fate of women to fight in the dark and ugly in the patriarchal society, thus realize the value of female subject full of personality and humanity.

\section{The religious fate of the characters' describe}

In the British gothic literature, fate is the most mysterious and powerful strength, it drives people's thought and life, is thought to be man can't control the ship, so, in the lack of scientific cognition s also more preach the importance of fate in the human religion. Hawthorne was born in the industrial revolution period, is a scientific transformation into the world of human beings, so he believed that science for society, for the human, bring force for literature. But on the other hand, Hawthorne also believe that the one hundred years of gothic "destiny" brought about by the deep-rooted influence for people, therefore, he thought, destiny will still create uncertainty and concerns to people's hearts. In this way, we can still see the theme of fate can't shape characters in Hawthorne's works. But in the description of the inevitable destiny, readers can see Hawthorne characters of human struggle, they embody in religion, good and evil, fatalism thought, this also works for him to add a bit of mystery and fantasy. From a practical point of view, the reader can see more works of human spirit and morality, this is fate depicting characters embodies Hawthorne in aspects of genius.

Hawthorne literary fatalism shows is human stand in front of fate that kind of lonely, embarrassing helpless situation, so at this point in Hawthorne's works includes early gothic literature emphasizes 
the shadow of destiny disillusionment. But in Hawthorne's fatalism and religious morality, the characters in the works just like in the face of faith in the face of the fate can't resist, can't dominate, and only obey. In his work "an aspiring visitors," the author describes a family living in the valley and a mystery guest, they seemed to have is on the verge of death premonition, seems to have to come to the ready prepared for death. But when landslides arrives, the whole family still made an instinctive resistance to fate, they rushed out of the house asylum, but all resistance is futile, landslide burst pounce on their house and blocked their living way, at this moment, the fate of the best interpretation of playful life clear theme, it tells people that fate is irreversible, people can accept.

In the "empty tears behind ", the opposite of expressed the people to the fate of gratitude, Margaret and Mary's husband is a sailor, two people are concerned about their husband each voyage will come on the sea, the rhythm of emotional beyond words, is ready to accept her husband out the fate of the misfortune. And every time after the news, they learned that her husband's safe return they will bow down to Thanksgiving to god, thank god of fortune for their generous regard it. In a nutshell, Hawthorne use different characters, different destiny lay religious and moral of fatalism, in later generations, it seems, his works extremely rich covers the early gothic literature destiny mysterious deep side, but the social type deepening of fatalism and let him out, it was a success ${ }^{[2]}$.

\section{The artistic technique of the Hawthorne}

Mentioned Hawthorne's symbolism literature in this paper several times, and this is his "American gothic" literature in independent artistic features. His inheritance and evolution of the gothic literature profoundly affected the later modernism literary genre in the development of symbolism and stream of consciousness literature. Have the posterity will Hawthorne's works as "remote valley with a pale color of flowers", is to illustrate his works full of ideal practice moral conscience, and the personality charm of literary works in the clever projection.

Hawthorne works widely used symbolism in art, in the atmosphere and the story theme and psychological aspects are used to symbolize the abstract concept, need to express is a word the meaning of aesthetic effect. Symbolism is the "image" of meaning expression; it carries on the deep implication, and broad extension of auxiliary work spirit. Just as Hegel said the symbol can be directly rendered in the perceptual care outward things, in and of itself, it implies is a relatively wide and universal human nature and social significance. "This sentence is used widely in interpretation of Hawthorne works and really cut loose and symbolism. It was widely that give more multifaceted meaning to his work, add the implicit style of work and mystery, let work charm is infinite. In Hawthorne literature of image expression, it uses the character image and details as the most brilliant.

\section{Hawthorne work art - the symbol of character image}

In Hawthorne's "the seven turrets," character image expresses deep connotation. The heroines in the two works Herpusiba with Phibe, a declining aristocracy is unable to adapt to modern life, she always do our best to maintain the dignity of the noble family and fair maiden, but to follow the tragic fate of her personality has become weak and fear; And the other is the outstanding representative of the New England civilians, she is kind, healthy, industrious and brave, and her inner purity and young forever, phoebe this trait is the symbol of love and the young people of hope and youth. Hawthorne to want to use the positive energy to eliminate Herpusiba inner darkness and fear, so the two heroines in the character of the works to form bright contrast, and dark table is the opposite of realistic social middleman, this stark contrast to the social conflict deduce incisively and vividly.

\section{Hawthorne works of the symbol art - image details}

Compared with image characters, hawthorne more fine details of image, he will be the society all valuable material arranged in a sequence, the combination of outstanding character's psychological, as the power of emotional expression, is the core part of the works series plot.Hawthorne image, pay attention to the details of the hidden psychological of the characters and the subconscious mind copy, so the characters in his works and the performance is so vivid and exquisite, let a person the feeling of autumn ${ }^{[3]}$.

In Hawthorne literary image expression, the details of the item image. Whether the perpetrator in black veil of imam black veil, and the bright red gem, let everyone is longing for ruby and these are 
their respective works, important items details throughout the story.Items from insight into the heart, it is hawthorne literary excellence, the reader through the veil of the hooper priest saw the heart of hidden crime's ambiguous attitude, so watch him from the human nature, alienated, the secrets of the veil from the pastor into loneliness; Readers also saw adventurers desire through a ruby, however, treasure hunters will die terrorist prophecy will let the human desire to an abrupt end.Ruby is showed, the symbol of human greed desire is that the Angle of the reflected the human fear of the unknown fate, so, "the bright red gem" has a dual moral irony of human nature, there are warnings to human desire.

\section{Conclusion}

In the long history of the western literary, Hawthorne's works are regarded as the name of the romantic, because he was the symbol of the independent ego consciousness and make public individual character of literary ideas. His creative inheritance of socialism in the early gothic literature emotional tone of the novel, but also opened up most romantic literature ideological trend of literature effect.In Henry James's view, hawthorne literature deeply explores the human mind and spirit of the deepest truth, also indicates the development direction of the future society, immutability with science, it is not available in the early gothic literature. And the use of symbolism literature skill also let him beyond the traditional gothic literature and art, an unprecedented height, for the later development of symbolism literary gave the important inspiration role.

\section{References}

[1] LiuYadong. Try analysis the Hawthorne of inheritance and innovation of traditional gothic literature. Journal of writer,2013,7(8):42-43.

[2] Yang Jie. Theory of hawthorne, the inheritance and transcendence of literary tradition of the gothic. Beijing language and culture university,2007,5-10.

[3] Liu Tingting. Theory of hawthorne creative inheritance of gothic novel and beyond. Nanjing normal university,2008.18-33. 